Japan. J. Breed., $34:$ 156 162 (1984)

\title{
The Relationship between Seed Fertility and Style Shortening after Pollination in Chrysanthemum
}

\author{
Kazumi Hatrori \\ Faculty of Agriculture, Nagoya University, Nagoya 464
}

\begin{abstract}
Experiments were carried out to determin the relationship between the style shortening observed shortly after pollination and the seed fertility (percent of fertile seeds to the total number of disc florets on each flower head). 1. It was found that the morphological difference existed between shortened style and unshortened style observed shortly after pollination was maintained until the seed maturation. 2 . Where times of pollination were varied, both percentage of disc florets with shortened style to the total number of disc florets on each flower head and seed fertility increased with increased time of pollination. Moreover, in the disc florets without the shortened style, no seed was. harvested. 3. In the case where self- and cross-pollination were made throughout the whole flowering period, it was observed that the percentage of disc florets with shortened style on each flower head and the seed fertility showed the various values, and the relationship between them was highly and positively correlated. Therefore, it. was suggested that crossing for seed production could be done rapidly by observing whether the style shortened or otherwise after pollination. 4. To determine the status of the style shortening in the natural condition, observation on disc florets on each of flower head after open-pollination was carried out. In this case also, the relation between the paercentage of disc florets with shortened style to the total number of disc florets on each flower head and seed fertility was highly and positively correlated. This confirmed that the style shortening observed shortly after compatible pollination was the general phenomenon in the disc floret of chrysanthemum.

KEY WORDS : Chrysanthemum morifolium, style shortening, seed fertility, disc floret, compatible pollination.
\end{abstract}

\section{Introduction}

Chrysanthemums are genetically controlled sporophytic self-incompatible (DREwrow et al., 1973), by which the tube penetration to the stigma is prevented. Moreover, even if they fertilized, one must wait about 8 weeks after pollination before the seeds of chrysanthemum matured. In the chrysanthemum breeding program, it would be desirable to determine, shortly after pollination, whether a crossing is successful or otherwise. DREWLow et al. (1975) suggested that the occurrence of seed set on each of the flower head could be predicted by using the method of counting the number of brown stigmas with pollen grains 8 days after pollination.

As that of several other Compositae species, the pollen viability of chrysanthemum is difficult to determine in vitro (Tsukamoto and Matsubara, 1968). It would therefore be useful to devise another testing method for determining the pollen viability. DE JoNG and KHo (1982) described that the shriveling of the pistils as observed a day after pollinating the disc florets of chrysanthemum would usually be followed by a good seed set 8 weeks later, suggesting that the easily visible pistil shriveling was a rapid in vivo test of pollen viability.

The author noticed that a shortening of the chrysanthemum style began to occur within several hours after pollination. The present study was undertaken to confirm

Received October 14, 1983 
whether this phenomenon bears relation to seed fertility.

\section{Materials and Methods}

Self-, cross- and open-pollination were made on emasculated or non-emasculated disc florets, but not on ray florets, of flower head of chrysanthemum grown in the greenhouse.

In the first experiment, the number of repeated pollinations between chrysanthemum. cultivars 'White Marble'(non-emasculated disc florets) and 'Bonnie Jean' ranged from 1 to 8 times. In addition, the pollination was carried out throughout the whole flowering: period. The pollination was done once a day. 'White Marble' is of male-sterility type though it rarely makes a few pollen grains. Therefore, non-emasculated disc florets. were used in this experiment.

8 weeks after pollination, flower heads were collected for observation on the styles. Each disc floret was observed whether it had shortened or unaffected, and whether it had fertile or sterile seed. The floret that had a stigma withdrawn into corolla was. rated as the floret with shortened style.

To test the use the style shortening for the actual breeding program, self- and crosspollinations were made throughout the whole flowering period, for the second experiment. The chrysanthemum cultivars, 'White Marble', 'Pink Marble', 'Bonnie Jean', 'Yellow Bonnie Jean', 'Tuneful' and 'Pink Daisy' were used for self- pollination. For crosspollination, 'White Marble' $\times$ 'Yellow Bonnie Jean' and 'Pink Marble' $\times$ 'Pink Daisy' were made.

Further, in the third experiment, open-pollinated flowers of 'White Marble', 'Yellow Bonnie Jean' and 'Yellow Delaware' $\times$ Chrysanthemum japonense $\mathrm{F}_{1}$ plants were observed.

The observation of the second and third experiments were made on the same method. as the first experiment.

\section{Results}

In the preliminary experiment, the progressive change of the disc florets after pollination: were observed. Fig. 1 shows that they are outer disc florets with shortened styles and inner florets with unshortened styles. This flower head, 8 days after pollination, was.

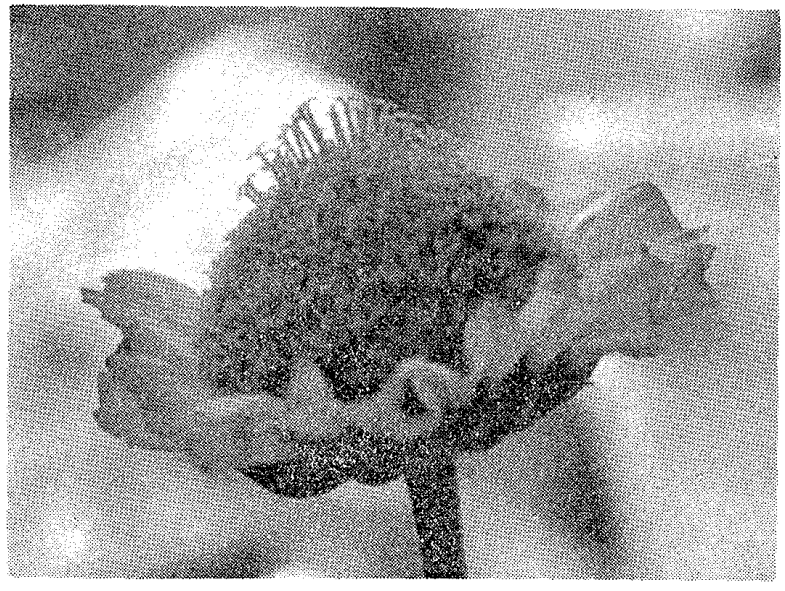

Fig. 1. The flower head pollinated 4 times to 'White Marble' by the pollens of 'Bonnie Jean', 8 days after pollination.

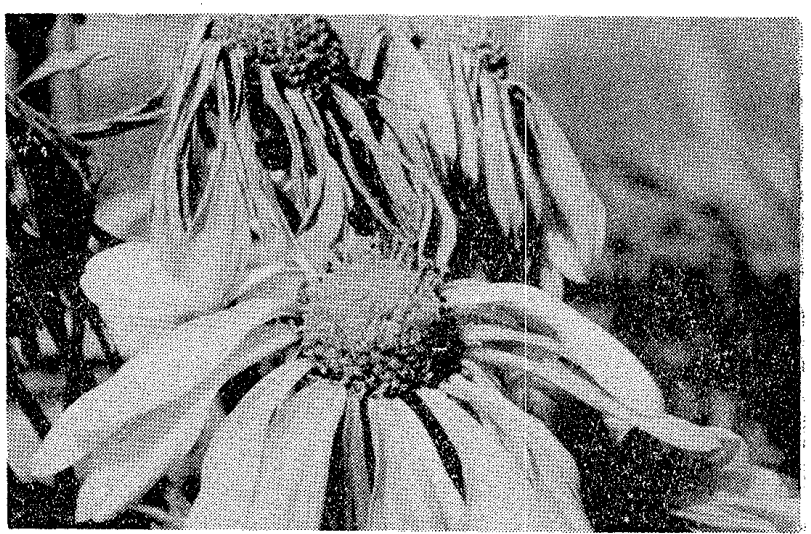

Fig. 2. The flower head of Open-pollinated $\mathrm{F}_{1}$ plant ('Yellow Delaware' $\times$ Chrysanthemum japonense) about 2 weeks. after whole flowering. 


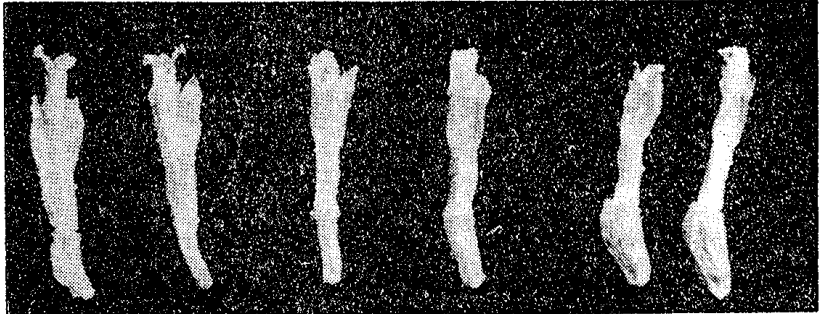

Fig. 3. The disc florets of open-pollinated plant of 'White Marble' about 2 months after fully flowering. The 2 florets on the right side have the fertile seeds with shortened styles. The center 2 florets have the sterile seeds with shortened styles. The 2 florets on the left side have the sterile seeds with unshoetened styles.

pollinated 4 times to 'White Marble' by the pollen of 'Bonnie Jean'. It was observed that the pollinated disc florets produced shortened styles. On the contrary, none of unpollinated disc florets had shortened styles. Fig. 2 shows the flower head of an open-pollinated $F_{1}$ plant about 2 weeks after whole flowering (innermost disc florets flowering) of 'Yellow Delaware' $\times$ Chrysanthemum japonense. It can be clearly seen whether the disc floret has a shortened style or otherwise. Fig. 3 shows the disc florets of open-pollinated plant of 'White Marble' about 2 months after flowering. The 2 florets on the right side have the fertile seeds with shortened styles. The center 2 florets have the sterile seeds with shortened styles. The 2 florets on the left side have the sterile seeds with unshortened styles.

The results of the first experiment are shown in the Table 1 and Fig. 4 . Table 1 shows the relationship between the number of disc florets with shortened style, the number of seeds and the number of pollination carried out. Both the number of disc florets with shortened styles and the number of seeds appear to increase with increase

Table 1 The relationship among the number of disc florets with shortened style, the number of seeds and the number of times of pollination.

\begin{tabular}{|c|c|c|c|c|c|c|c|c|c|}
\hline & \multicolumn{8}{|c|}{ No. of times of pollination } & \multirow{2}{*}{$\begin{array}{c}\text { whole } \\
\text { flowering } \\
\text { period }\end{array}$} \\
\hline & 1 & 2 & 3 & 4 & 5 & 6 & 7 & 8 & \\
\hline $\begin{array}{l}\text { No. of flower } \\
\text { heads tested }\end{array}$ & 5 & 2 & 2 & 2 & 2 & 2 & 2 & 2 & 5 \\
\hline $\begin{array}{l}\text { No. of disc } \\
\text { florets tested }\end{array}$ & 1,192 & 472 & 500 & 504 & 444 & 486 & 492 & $450^{\circ}$ & 1,256 \\
\hline $\begin{array}{l}\text { No. of disc } \\
\text { florets with } \\
\text { shortened style }(\%)\end{array}$ & $\begin{array}{r}322 \\
(27.0)\end{array}$ & $\begin{array}{r}284 \\
(51.7)\end{array}$ & $\begin{array}{r}353 \\
(70.6)\end{array}$ & $\begin{array}{r}367 \\
(72.8)\end{array}$ & $\begin{array}{r}373 \\
(84.0)\end{array}$ & $\begin{array}{r}430 \\
(88.5)\end{array}$ & $\begin{array}{r}413 \\
(83.9)\end{array}$ & $\begin{array}{r}405 \\
(90.0)\end{array}$ & $\begin{array}{r}1,055 \\
(84.0)\end{array}$ \\
\hline $\begin{array}{l}\text { No. of seeds } \\
\text { harvested }(\%)\end{array}$ & $\begin{array}{r}151 \\
(12.7)\end{array}$ & $\begin{array}{r}124 \\
(26.3)\end{array}$ & $\begin{array}{r}183 \\
(36.6)\end{array}$ & $\begin{array}{r}199 \\
(39.5)\end{array}$ & $\begin{array}{r}209 \\
(40.1)\end{array}$ & $\begin{array}{r}234 \\
(48.1)\end{array}$ & $\begin{array}{r}246 \\
(50.0)\end{array}$ & $\begin{array}{r}262 \\
(58.2)\end{array}$ & $\begin{array}{r}664 \\
(52.9)\end{array}$ \\
\hline
\end{tabular}


Table 2. The total number of tested florets and the number of seeds harvested from florets without shortened styles in each experiment.

\begin{tabular}{lccccc} 
& $\begin{array}{c}\text { No. of flower } \\
\text { heads tested }\end{array}$ & $\begin{array}{c}\text { No. of florets } \\
\text { tested }\end{array}$ & $\begin{array}{c}\text { No. of florets } \\
\text { with shortened } \\
\text { style }\end{array}$ & $\begin{array}{c}\text { No. of seeds } \\
\text { harvested }\end{array}$ & $\begin{array}{c}\text { No. of seeds of } \\
\text { florets without } \\
\text { shortened style }\end{array}$ \\
\hline 1 st experiment* & 24 & 5,796 & 3,902 & 2,272 & 0 \\
2 nd experiment & 58 & 13,491 & 8,345 & 4,210 & $36^{* *}$ \\
3 rd experiment & 42 & 7,423 & 4,292 & 2,213 & 10
\end{tabular}

* I st experiment : the 1 to 8 times of pollination and the whole flowering period of pollination

2 nd experiment : the self- and cross-pollination through whole flowering period

$3 \mathrm{rd}$ experiment : the open-pollination

** These were observed only self-pollination of 'Pink Daisy'

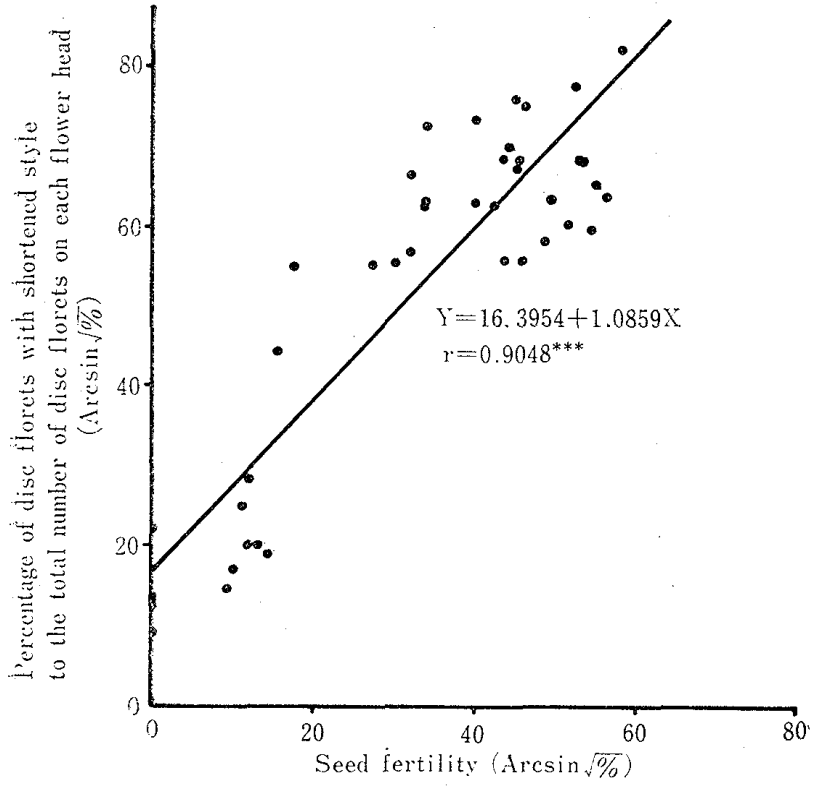

Fig. 5. The relation between the seed fertility and the ratio of disc florets with shortened style in the self- and crosspollination through whole flowering period.

$* * *$ : significant at $0.1 \%$ level

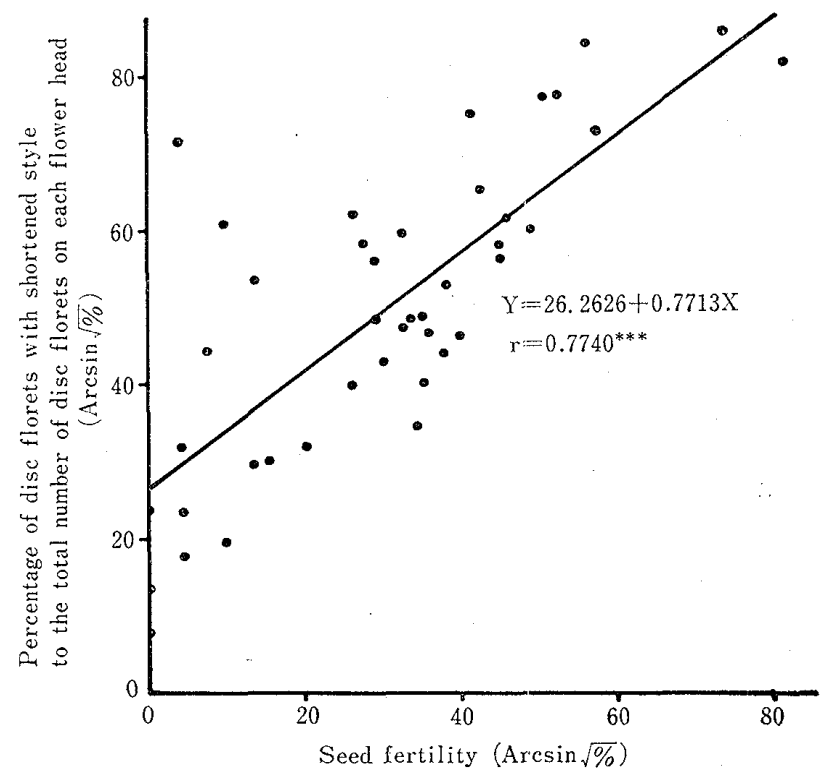

Fig. 6. The relation between the seed fertility and the ratio of disc florets with shortened style in the open-pollination.

*** : significant at $0.1 \%$ level

in the number of pollinations carried out. Further, the 7 and 8 times of pollination seem to be the same seed fertility as the pollination throughout whole flowering period. This is regarded as the correct result from which the whole flowering period (the flowering period from outermost disc floret to innermost disc floret) is about one week. Fig. 4 shows the relation between the seed fertility (percent of fertile seeds to the total number of disc florets on each flower head) and the percentage of disc florets with shortened style to the total number of disc florets on each flower head during the period of pollination. The correlation coefficient between them was very high $(r=0.9596$, significance at $0.1 \%$ level). This suggested that the style shortening after pollination has relation with seed formation. Moreover, it appeared that shortening of the style was a necessary condition for seed formation, since no seeds were observed in the disc florets with unshortened styles. 
In the second experiment, the result (in Fig. 5) again showed that the relation betweer the seed fertility and the percentage of disc florets with shortened style to the total number of disc florets on each flower head is highly correlated $(r=0.9048$, significance at $0.1 \%$ level). In this experiment, self-pollination of 'Tuneful' did not produce any' seeds as expected since it is self-incompatible. Futher, 'White Marble' and 'Pink Marble" that belong to the same sport family produce a few seeds. Although these varieties express the male-sterility, the outer disc florets frequently produce a few pollen grains, which fertilized a few disc florets. Therefore, they were identified as self-compatible varieties.

Fig. 6 shows the relation between the seed fertility and the percentage of disc florets with shortened style to the total number of disc florets on each flower head in the open-pollination (the third experiment). The correlation is not as high as compared with results from the first and second experiments, correlation coefficient being $r=0.7740$, significant at $0.1 \%$ level. This suggested that the style shortening after pollination could occur not only by the artificial pollination but also under natural state.

Table 2 shows the total number of tested disc florets and harvested seeds without style shortening in each experiment. In the first experiment, florets without shortened style did not produce any seeds. In the second and third experiments, florets without shortened style produced a few seeds. In these florets, the stigma did not withdraw completely into corolla, but the style shortened as compared with the style of sterile floret. In the second experiment, these seeds were obtained from only self-pollination of 'Pink Daisy'.

Therefore, it was considered that the style shortening after pollination was the general: phenomenon in chrysanthemum.

\section{Discussion}

In this experiment, it is demonstrated that the phenomenon where the style of disc floret of a cultivated chrysanthemum shortens just after compatible pollination continues until seed ripening stage at the 8 weeks after pollination, and is related to the seed fertility. Moreover, this phenomenon appeared to be a necessary condition for the seed set, since about fifty percent of florets with shortened style, as shown in Table 2, produced fertlie seeds.

The occurrence of seed set can be predicted with high accuracy by examining of stigma browning at 8 days after pollination without waiting the 1 to 2 months required for seed ripening in Chrysanthemum morifolium (Drewlow et al., 1975). The style shortening of disc florets of chrysanthemum, in this experiment, occurred several hours after pollination and was the easily visible phenomenon for prediction of seed set without waiting for seed ripening.

DE JONG and KHO (1982) reported that shriveling of pistils observed one day after pollination of the disc florets of chrysanthemum was normally followed by a good seed set 8 weeks later, and this was suggested to be useful as a rapid in vivo test of pollen viability. However, the relationship between shriveling of pistil and seed set could not be established in the same floret by the above workers. In this experiment, results 
showed that the style shortening occurred shortly after pollination and the relationship between the shortening of style and the seed fertility in the same floret was more established.

In Petunia hybrida, the ovary is stimulated to synthesize proteins before the pollen tubes reach the ovary. A signal has to be sent from the stigma or the style toward the ovary which induces the change in metabolic activity and the signal is different for cross- and self-pollination (Duerenberg, 1976). Pollen tube growth in the style accelerated wilting of Petunia flower (Grlissen, 1976). It is also suggested that the style is sense-organ with regard to the transmission of information from stigma and style to other flower organs.

In chrysanthemums, the styles of the disc florets shorten shortly after a compatible pollination leading to seed formation. If the styles normally shorten within several hours after pollination, the pollen tubes do not reach the ovary, and may not reach the style when the style shortening occurs. It is thought that the stigma is senseorgan to recognize the compatible or incompatible pollens attaching in chrysanthemums.

In the chrysanthemum breeding program, it is very important that the self- and cross-incompatibility can be determined rapidly. The self-incompatibility reaction in the garden chrysanthemum is sporophytic and involves more than 1 locus (Drewlow et al., 1973), and a self-compatible plant is found to occur only rarely in the normally self-incompatible garden chrysanthemum (Ronald and Ascher, 1975 a). Self-compatibility may prove useful in genetic analysis and in development of inbred lines and subsequently $\mathrm{F}_{1}$ hybrid chrysanthemum (Ronald and Ascher, $1975 \mathrm{~b}$ ). The phenomenon that the style of the disc floret shortens shortly after compatible pollination may be used as rapid test of self- and cross- incompatibility in chrysanthemum.

It was thought that the style shortening is a necessary condition to produce seeds, since the florets without shortened styles did not produce seed harvested. Moreover, only about a half of the florets with shortened styles produce seed harvested. These suggested that there are many complex factors in the process from the pollination to the seed formation, and that these factors may play their role through these process. Therefore, the style shortening may be controlled by one or more factors situated at the very early stage of the process.

\section{Acknowledgement}

The author is greatfully indebted to Dr. Y. Futsuhara, Faculty of Agriculture of Nagoya University, for his valuable advice and encouragement and correction of this manuscript.

\section{Literature Cited}

DEURENBERG, J. J. M. 1976. In vitro protein synthesis with polysomes from unpollinated, cross- and self-pollinated Petunia ovaries. Planta 128:29 33.

DREWLOW, L. W., P.D. ASCHER and R.E. WIDMER 1973. Genetic studies of self incompatibility in the garden chrysanthemum, Chrysanthemum morifolium Ramat. Theoret. Appl. Genet. 43:1 5.

Chrysanthemum morifolium Ramat. Euphytica $24: 29 \sim 32$.

GILISSEN, L. J.W. 1976. The role of the style as a sense-organ in relation to wilting of the flower. 
Planta 131 : 201 202.

JONG, J. DE and Y.O. KHO 1982. The shriveling of pollinated pistils as an aid to rapid determination of chrysanthemum pollen viability. Euphytica $31: 519 \sim 521$.

RONALD, W. G. and P.D. ASCHER 1975 a. Self compatibility in garden Chrysanthemum : occurrence, inheritance and breeding potential. Theoret. Appl. Genet. $46: 45 \sim 54$.

and - 1975 b. Transfer of self compatibility from garden to greenhouse strains of Chrysanthemum morifolium Ramat. J. Amer. Soc. Hort. Sci. 100:351 353.

TSUKAMOTO, Y. and S. MATSUBARA 1968. Studies on germination of chrysanthemum pollen. I. Effect of sugars on germination. Plant \& Cell physiol. $9: 227 \sim 235$.

キクに步ける授粉後の花柱短縮と種子稔性の関係

\author{
服部 一三 \\ （名占屋大学農学部，名古屋甫）
}

キクの授粉直後に観察される花柱短縮と約 8 週間後の種子稔性との関係を明らかにするために実駼を行った。

1. 授粉直後に観察される短縮花柱和よび非短縮花柱の間の形態的な差異は完熟種子形成期るで維持される。

2. 授粉回数を変えた場合には，授粉回数が多い注ど，短縮花柱をもつ管状花率（1頭状花序あたりの全管状 花数に対する短縮花柱をもつ管状花数の百分率) 执よび種子稔性（1頭状花序あたりの全管状花数に対する稔笑 種子数の百分率)が增加した。さらに，短繀花柱をもたない管状花では種子はまったく得られなかった。

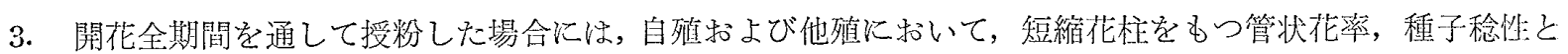
も種々の值を示するのが钼察された。これらの間には高い正の相関々係が存在した。このことから，授粉值後に 花柱短縮の有無を調查することにより採種可能な交配組合せを早期に選別できることが示唆された。

4. 自然状態に拈る花柱短縮の状沉を明らかにするために放任授粉後の調查を行った。この場合にも短縮花 柱をるつ管状花率と種子稔性との間には高い正の相関々係が存在した。すなわち, 和合花粉を授粉した直後に観 察される花柱の短縮はキクの管状花では一般的な現领であることが確認された。 